GENETIC COMPLEMENTATION ANALYSIS OF MEVALONATE KINASE DEFICIENCY IN CULTURED FIBROBLASTS

125 Kenneth $M$. Gibson and Georg F. Hoffmann Department of Neuropediatrics, University of Heidelberg, Federal Republic of Germany

Mevalonate kinase deflciency (MKD), an inborn error of sterol synthesis, presents with clinical variability. To define a genetic basis for this variability, we determined $M K$ activity in fibroblast heterokaryons deined from polyethylene glycol fusion. Fusion of control fibroblasts with 6 MKD cell lines yielded positive complementation ( 378 of control activity). None of the fuslons between the 6 MKD cell lines ylelded detectable MK activity. Michaelis constants in an MK assay optimlzed for use in blopsied chorionic villi (BCV) were 0.06 and $0.7 \mathrm{mM}$ for mevalonate and ATP, respectively. MK activity in control BCV increased linearly $(0.8-4.3$ $\mathrm{nmol} / \mathrm{m} 1 \mathrm{n} / \mathrm{mg}$ proteln) with gestational age from 7 to is weeks. MK activity in BCV from a pregnancy at risk for MKD was $430 \mathrm{pmol} / \mathrm{min} / \mathrm{mg}$ protein, suggesting an unaffected fetus. We conclude there is no evidence for genetic heterogeneity in MKD which would explain the genetility in clinical expression. optimized MK assay for use in The availability of an trime trimester prenatal diagnosis for families at risk.

\section{ANALYSIS OF MUTANT PKU ALLELES IN THE
POPULATION OF SOUTHERN POLAND}

126 Marta Żygulska, Jacek J.Pietrzyk, Agnieszka Sutkowska, Antoni Eigel, Bernd Dworniczak, Jürgen Horst Dept.of Med.Genet., Medical Academy, Kraków, Poland and Institute of Human Genetics, Univ.of Münster, FRG

A sample of 22 PKU probands were screened for six mutations by polymerase chain reaction (PCR) amplification of their genomic DNA and hybridization with allele-specific-oligonucleotides. The following mutations were tested: exon 5,codon 158 (CGG-CAG); exon 7, codon 261 (CGACAA), codon 281 (CCT-CTT); exon 12,5' splice donor site (GT-AT), codon 414 (TAC-TGC) and codon 408 (CGT-TGG). Dot-blot hybridization with 32P labelled ASO was used to detect the presence of the mutations. Results: The analysis covered 44 mutant chromosomes from 22 unrelated PKU children. About $66 \%$ of PKU alleles studied were characterized by three distinct mutations: in codon 408,158 and 261 , with codon $408(56.8 \%)$ being the most prevalent and tightly linked to haplotype (HT) 2 . The codon 158 and 261 mutations were found in $6.8 \%$ and $2.3 \%$ of all PKU alleles, respectively. The missence mutation in codon 158 was detected in 2 patients who suffered from the classical form of PKU, and was linked to HT 4 . The $G$ to A transition in codon 261 was only found in a single chromosome and was linked to HT 1. No mutant PAH gene exhibiting the splicing defect in intron 12, neither the mutations in codon 414 and 281 was identified. Our results confirm molecular heterogeneity of PKU and show that the majority $(66 \%)$ of all PKU alleles are characterized by three different mutations.

SECONDARY HYPERPARATHYROIDISM IN A PRETERM INFANT CAUSED BY HIGH PLASMA PROTEIN CONCENTRATION

Paurma, F. Pohlandt and L Gortner

Children's Hospital, University of Ulm, D-7900 Ulm, Germany

The intrauterine bone mineral accretion rate can be achieved in preterm infants by supplementation with calcium $(\mathrm{Ca})$ and phosphorus $(\mathrm{Pi})$ up to the point where both ions are simultaneously excreted with urine. We report on a female preterm infant (birth weight $1030 \mathrm{~g}$, gestational age 29 weeks) who unexpectedly developed bone mineral deficieny, measured by single photon absorption densitometry at right mid humerus $\left(67 \mathrm{mg} \mathrm{cm}^{-1}\right.$ at $1530 \mathrm{~g}$ body weight on day 60$)$, in spite of rather high plasma concentrations of Ca $(2.6-2.9$ $\mathrm{mmol} / \mathrm{l})$ and $\mathrm{Pi}(2.2-3.0 \mathrm{mmol} / \mathrm{l})$ as well as constant urinary excretion of and $\mathrm{Pi}$. The explanation was found to be an unusual high plasma total protein concentration $(82 \mathrm{~g} / \mathrm{l}$ at birth decreasing to 74 on day 54 ) leading to low ionized $\mathrm{Ca}(0.85-0.95 \mathrm{mmol} / 1)$. This subsequently caused secondary hyperparathyroidism $(330 \mathrm{pg} / \mathrm{ml}, 1-84$ assay, on day 50$)$ and osteopenia. Oral Ca gluconate $\left(1-2 \mathrm{mmol} \mathrm{kg}{ }^{-1}\right.$ day $\left.^{-1}\right)$ increased ionized Ca $(1.1 \mathrm{M})$, normalized plasma PTH $(27 \mathrm{pg} / \mathrm{l})$ and allowed good bone mineralization $\left(27 \mathrm{mg} \mathrm{cm}^{-1}\right.$ per $520 \mathrm{~g}$ weight gain), which equaled to the intrauterine rate $\left(4.4 \mathrm{mg} \mathrm{cm}^{-1}\right.$ per $100 \mathrm{~g}$ weight gain). Conclusion: Ionized, not total, plasma $\mathrm{Ca}$ is relevant to mineralization. In case of high protein concentration calciuria does not reliably indicate calcium surplus as usually and $\mathrm{Ca}$ supplementation should be increased until ionized $\mathrm{Ca}$ is normal to achieve normal mineralization.
LONGITUDINAL LUMBAR BONE MINERAL MEASUREMENTS BY DUAL ENERGY X RAY ABSORPTIOMETRY IN PREMATURE

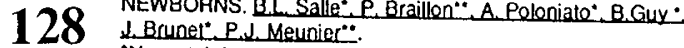

"Neonatal department and " "Unit INSERM 234 - Hôpital Edouard Herriot Lyon - France.

Dual energy X Ray absorptiometry (DXA) was used to measured the bone minera
content (BMC) and bone minerai density (BMD) during the first year of lite. Mean birth weight was $1290 \pm 150$ in in 29 premature newborns was $30.4 \pm 0.5$ weeks. There were studied at day $40 \pm 4,59 \pm 1,187 \pm 2 \theta 365 \pm 5$ posinal a age. The data compared to normal value obtained in infants less than 2 years old are shown in table (mean \pm SEM).

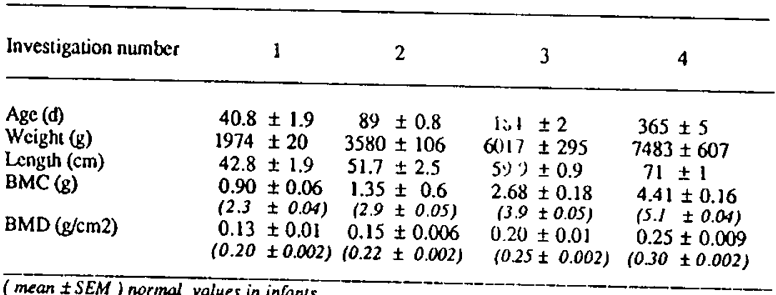

(mean $\pm S E M)$ normal values in infants

Moan BMC and BMD were signiticant lower in premature babies than in normal iffants during the first 6 months or
different between the two groups.
INCREASED CONCENTRATION OF 25-HYDROXYVITAMIN D (25D) AND 1,25 DIHYDROXYVITAMIN D $(1,25)$ RECEPTORS IN KIDNEYS OF

129 RA'S TREATED WITH PHENOBARBITAL (PB). Manuel Moya* Isabel Ballester; María José Campello; Ernesto Cortés. Pediatric Dep. University of Alicante. Alicante. Spain. Chronic administration of $\mathrm{PB}$ and other anticonvulsant drugs can induce hypocalcemia and osteopenja. A decreased plasm 250 concentration can be responsible, and maybe other derangements of 1,25D. The study of receptor concentration in a target tissue (kidney) will inform on the performance of vitamin $D$ metabolites. Ten wistar rats were treated with $P B(6 \mathrm{mg} / \mathrm{Kg} / \mathrm{d})$ from the $21 \mathrm{st}$ day of life for ten weeks. At this time, whole blood was obtained, both kidneys were removed for $25 \mathrm{D}$ and $1,25 \mathrm{D}$ receptor quantitation (Reinhart, Hollis 1986). Control group included 5 rats.

\begin{tabular}{|c|c|c|c|c|}
\hline & \multicolumn{2}{|c|}{$25 \mathrm{D}$} & \multicolumn{2}{|c|}{$1.25 \mathrm{D}$} \\
\hline & Control & $\mathrm{PB}$ & Control & PB \\
\hline$B \max (\mathrm{pm} / \mathrm{mg})$ & $\begin{array}{l}1.8(1.4) \\
4.3(0.6)\end{array}$ & $\begin{array}{l}2.0(1.6) \\
6.4(1.4)\end{array}$ & $0.5(0.1)$ & $\begin{array}{r}0.5(0.2) \\
* \quad 134.6(62.8\end{array}$ \\
\hline
\end{tabular}

Plasma values showed no differences apart from 250 which was respectively $8.3(2.4)$ and $5.2(2.3) \mathrm{ng} / \mathrm{ml}(\mathrm{p}<0.05)$. Rajsed concentration of $25 \mathrm{D}$ receptors is in agreement with low hase output. Converseley raised concentration of 1,25 receptors sugges a normal response for calcium reabsorption, ahd up-regulation response or a direct induction of $P B$ over ald -regulation requiring further studies. CAICYT PM. 89 over $1 \alpha$-hydroxilase, PLASMA OSTEOCALCIN LEVELS IN VITAMIN D DEFI-
CIENCY RICKETS

130 Eric Mallet, Jean-Paul Basuyau, Philippe Brunelle - Service de Pédiatrie et Laboratoire de Biologie du Développenent, Centre Hospitalo-Universitaire, 76031 Rouen Cédex, France

In order to evaluate the interest of osteocalcin, which is synthetized in bone concomitant with the appearance of mineralized bone, we studied 20 infants aged 7 to 15 months with vitamin D deficiency rickets, before and after treatment $\left(1000 \mathrm{mg} / \mathrm{m}^{2}\right.$ calcium and $2.5 \mathrm{mg}$ vitamine D). Serum alkaline phosphatases (ALP) levels, bone and liver isoenzymes, were measured by Bio Merieux Kit, isoenzymes by cellulose acetate electrophoresis ; 25 and 1.25 dihydroxy vitamin $D$ were measured according to Shepard method; intact parathyroïd hormon by Nichols kit. Before treatment to the serum osteocalcin and vitamin $D$ metabolites levels were lower in infants with rickets than in control subjects. A significant change and rise was observed as soon as 1 week after treatment. In contrast, ALP and its bone isoenzyme levels were elevated before treatment and did not change significantly over 4 weeks, and secondary hyperparathyrö̈dism was reduced afier 2 or 3 weeks. To conclude osteocalcin appears to be an early indicator of bone response to treatment in vitamine D deficiency rickets and its low level before treatment might be due to decreased vitamine $\mathrm{D}$ metabolites levels rather than hyperparathyroïdism. 